\title{
Polymeric IgA myeloma, hyperlipidaemia and xanthomatosis: a further case and review
}

\author{
P. J. ROBERTS-THOMSON* \\ M.B., B.S. \\ G. S. Venables* \\ B.A., B.M., B.Ch. \\ A. C. ONITIRI $\dagger$ \\ B.Sc., M.B., B.S., M.Sc. \\ B. LEWIS $\dagger$ \\ M.D., Ph.D., M.R.C.Path., M.R.C.P. \\ * Nuffield Department of Clinical Medicine, Radcliffe Infirmary, Oxford and \\ $\dagger$ Department of Chemical Pathology, Royal Postgraduate Medical School, London
}

\begin{abstract}
Summary
A patient is described who had myeloma of the polymeric IgA variety, together with a striking hyperlipidaemia and xanthomatosis. Investigations into the protein and lipid abnormality failed to demonstrate any mechanism for the hyperlipidaemia. A review of the literature, however, validates this clinical entity and some of the suggested explanations are discussed.
\end{abstract}

\section{Introduction}

The sera of patients with multiple myeloma or Waldenström's macroglobulinaemia may show concurrent hypolipidaemia (Liebetseder et al., 1951; Feiereis and Sehnert, 1954; Gross and Weicker, 1954; Lewis and Page, 1954; Kanzow, 1957; Seitanides, Shulman and Hobbs, 1970), normal lipids (Magalini, Stefanini and Martin, 1956) or hyperlipidaemia. The majority show a depression of their blood lipids and this may relate to the paucity at autopsy of significant atheroma (Spain et al., 1956). Riesen, Noseda and Butler (1971) have suggested, with experimental evidence, that the hypolipidaemia is due to the formation of lipoprotein ' $M$ ' component complexes which are rapidly cleared from the circulation.

During the last three decades several authors have noted the approximately simultaneous occurrence of myeloma and hyperlipidaemia with cutaneous xanthomatosis. The myeloma is usually of IgA or IgG class but IgM paraprotein may also be involved (J. R. Hobbs, personal communication). Beaumont, Jacotot and Beaumont (1967) and Beaumont (1969) have demonstrated complexing of the myeloma paraprotein with the lipoprotein. In one of these cases, an IgG myeloma, he showed the binding activity for the lipoprotein resided in the Fab por-

Correspondence: P. Roberts-Thomson, Immunology Unit, Nuffield Department of Clinical Medicine, Radcliffe Infirmary, Oxford. tion of the molecule. He suggested that these cases were an example of myeloma with auto-antibody activity and that the process of binding decreased the catabolic rate of the lipoprotein. He further suggested that the deposition of this complex in arterial wall and tissues may be likened to the deposition of immune complexes as shown experimentally in serum sickness (Kniker and Cochrane, 1968).

This communication describes a patient with a polymeric kappa IgA myeloma, associated with hyperlipidaemia and a non-familial 'eruptive' xanthomatosis. In this patient no evidence was obtained of the association of the paraprotein with the lipoprotein; the explanation for this clinical entity may have to be expanded to include such cases.

\section{Case report}

A 58-year-old white Caucasian, chauffeur and gardener, presented with an influenza-like illness. An erythrocyte sedimentation rate (ESR) of $50 \mathrm{~mm} /$ first hour was noted. His symptoms abated but during the next 18 months his ESR varied between 40 and $50 \mathrm{~mm} / \mathrm{hr}$. Then 4 months later the ESR was $108 \mathrm{~mm} / \mathrm{hr}$, total protein $8.5 \mathrm{~g} / 100 \mathrm{ml}$ with serum albumin of $3.7 \mathrm{~g} / 100 \mathrm{ml}$, haemoglobin $(\mathrm{Hb}) 14 / 6 \mathrm{~g} /$ $100 \mathrm{ml}$, and a serum cholesterol of $440 \mathrm{mg} / 100 \mathrm{ml}$ with neutral fats of $600 \mathrm{mg} / 100 \mathrm{ml}$. His serum was 'milky' and the lipid electrophoretic pattern showed a dense $\beta$ band with additional staining at the origin.

Two years after the onset of his illness the patient developed exacerbation of long-standing lumbar backache and had moderate epistaxis. X-ray showed mid-thoracic vertebral body collapse. The $\mathrm{Hb}$ was $40 \%$ and a sternal marrow showed diffuse infiltration of large abnormal plasma cells, macronormoblastic erythropoiesis and increased basophils. He was referred to the Radcliffe Infirmary and was admitted 
in January 1973, with the diagnosis of multiple myeloma. Past medical history was non-contributory. The patient rarely drank alcohol. He had eight siblings and two children, with no family history of xanthoma, premature ischaemic heart disease, diabetes or cancer. Six elder siblings were alive and well.

Examination revealed a pale thin man of small build, weight $51 \mathrm{~kg}$. Multiple small (1-3 $\mathrm{mm}$ ) raised yellow plaques were noted on the extensor aspects of the elbows and knees (Fig. 1), on the front of the chest and abdomen and on the back of the chest. They were not surrounded by cutaneous erythema or induration. In his palmar creases were yelloworange linear depositions identical to those described in Type III hyperlipoproteinaemia (Fredrickson, Levy and Lees, 1967). No arcus senilis was seen. The liver was slightly enlarged but the spleen was not palpable. The sternum and dorsal spine were tender to percussion. Ophthalmic examination revealed bilateral flame-shaped retinal haemorrhages but no papilloedema. There were no abnormal cardiovascular signs, and the peripheral pulses were palpable and equal.

Investigations: $\mathrm{Hb} 11.9 \mathrm{~g} / 100 \mathrm{ml}$ with $6.2 \%$ reticulocytes; ESR (Westergren) $156 \mathrm{~mm} /$ first hour; WCC $11,500 / \mathrm{mm}^{3}, 56 \%$ neutrophils, $9 \%$ eosinophils, $2 \%$ basophils, $14 \%$ lymphocytes and $12 \%$

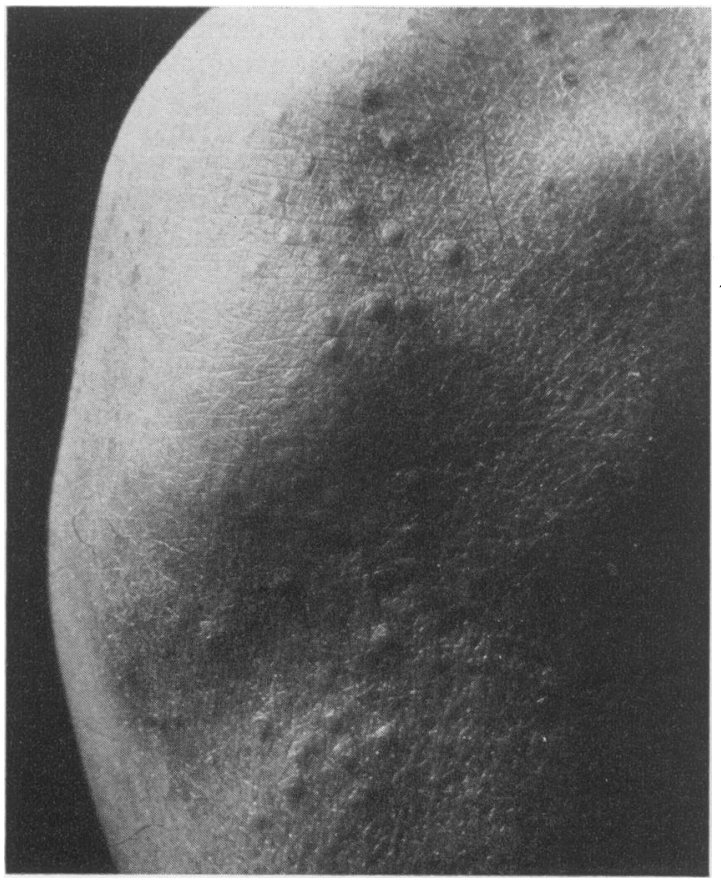

Fig. 1. Appearance of xanthomas of right knee. monocytes, platelets $320,000 / \mathrm{mm}^{3}$, PCV $25.8 \%$; serum iron $85 \mu \mathrm{g} / 100 \mathrm{ml}$ and total iron binding capacity $240 \mu \mathrm{g} / 100 \mathrm{ml}$. Total serum proteins were $11 \mathrm{~g} / 100 \mathrm{ml}$; albumin $2.4 \mathrm{~g} / 100 \mathrm{ml}$; serum calcium $13.1 \mathrm{mg} / 100 \mathrm{ml}$; inorganic phosphate $3.3 \mathrm{mg} / 100 \mathrm{ml}$. Serum protein electrophoresis demonstrated a discrete $\beta$ band and concentrated urine contained a similarily migrating band which reacted with antikappa serum. Serum immunoglobulins were: IgA $700 \mathrm{mg} / 100 \mathrm{ml}$; IgG $366 \mathrm{mg} / 100 \mathrm{ml}$; IgM $20 \mathrm{mg} /$ $100 \mathrm{ml}$. The Sia water test was negative and cryoglobulins were not demonstrated. The serum was turbid with total fasting cholesterol $356 \mathrm{mg} / 100 \mathrm{ml}$ and neutral fats $670 \mathrm{mg} / 100 \mathrm{ml}$. On agarose gel lipoprotein electrophoresis there were a markedly increased pre- $\beta$ band and increased density at the $\beta$ position and at the origin.

Biopsy of the lesion around the right knee showed foamy macrophages within the subcutaneous tissues consistent with the histological features of a xanthoma. Immunofluorescent studies (performed by Dr J. Skinner of the Department of Morbid Anatomy, Radcliffe Infirmary, Oxford) did not detect any IgA within these lesions. The bleeding and prothrombin times and factor VIII and XIII were normal. Platelet aggregation studies (performed by Dr M. Glynn of the Nuffield Department of Surgery, Radcliffe Infirmary, Oxford) showed a normal response to aggregating agents but washing the platelets produced an abnormally large enhancement of aggregation, suggesting the presence of coating protein. Serum viscosity studies (performed by Dr D. Mason of the Department of Pathology, Radcliffe Infirmary, Oxford) using an Ostwalt viscosimeter showed an elevated viscosity at $37^{\circ} \mathrm{C}$ of 2.8 relative to water $(\mathrm{N} 1 \cdot 3-1 \cdot 6)$. Normal results were obtained for serum electrolytes, fasting glucose, blood urea, uric acid and liver enzymes. Creatinine clearance was $77 \mathrm{ml} / \mathrm{min}$. Radiological studies were incomplete but showed collapse of several thoracic vertebrae.

The patient was treated with cyclophosphamide $50 \mathrm{mg}$ t.d.s. and prednisolone $5 \mathrm{mg}$ t.d.s. and discharged 3 years after onset of illness but was readmitted a month later with a chest infection and general deterioration including increasing back pain, repeated epistaxis, and nausea. The chest infection was controlled with antibiotics. Some of these features and the retinal haemorrhages suggested the hyperviscosity syndrome and plasmaphoresis was instituted, 41 of plasma being removed over the next 4 days with some improvement in mentation and general condition. Radiotherapy to the dorsal spine was commenced, the prednisolone increased to $10 \mathrm{mg}$ q.d.s. and over the next week the patient underwent further plasmaphoresis with some improvement. Only small changes in the total protein 
levels were observed although a considerable amount of protein was removed using a cell separator. Follow-up over the next 2 months showed a gradual response to cytotoxic treatment, the total serum protein dropping to $8 \mathrm{~g} / 100 \mathrm{ml}$ with albumin of $2.6 \mathrm{~g} / 100 \mathrm{ml}$. The haemoglobin remained in the range 11-13 g/100 $\mathrm{ml}$ and little change was observed in blood lipids. Serum remained constantly turbid and the appearance of the xanthomata was unchanged. The patient remained moderately well, then deteriorated 6 weeks before death from pneumonia, 3 years and 4 months after first being seen by us. Autopsy was refused.

\section{Special investigations}

\section{Material and methods}

Serum electrophoresis was performed in $1 \%$ Difco fine agar and $1 \%$ 'Miles-Seravac' agarose in $0.05 \mathrm{M}$ barbital buffer, pH 8.4. Azacarmine B, and Oil Red $O$ and Sudan Black were the protein and fat stains respectively. Wellcome immunoglobulin antiserum was used in the immunoelectrophoretic plates. Immunoselection was performed as according to Radl (1970). Gel chromatography was carried out in a $2.5 \times 41 \mathrm{~cm}$ column containing Sepharose $6 \mathrm{~B}$ (exclusion limit of $4 \times 10^{6}$ daltons) in phosphatebuffered saline pH $7 \cdot 2$ with an upward flow rate of $20 \mathrm{ml} / \mathrm{hr}$. The void volume was calibrated with dextran blue. The immunoglobulin levels in the eluates were assayed by radial immunodiffusion. Electrophoresis was also performed on polyacrylamide gel (PA) in the presence of sodium dodecyl sulphate (SDS) according to the method of Weber and Osborn (1969) in $100 \times 6 \mathrm{~mm} \mathrm{3.6 \%}$ and $7 \%$ PA gels $(\mathrm{T}=3.6 \%$ or $7 \%, \mathrm{~B}=3.6 \%)$ in $0.2 \%$ SDS in tris/acetate/EDTA buffer pH $7 \cdot 4 ; 10 \mu \mathrm{l}$ of serum diluted $1: 10$ in buffer and $2 \%$ SDS was applied with Bromoblue as albumin marker. Reduction of IgA myeloma protein in $2 \%$ dithiothreitol,
$8 \mathrm{~m}$ urea and $2 \%$ SDS was terminated after $1 \mathrm{hr}$ at $37^{\circ} \mathrm{C}$ with $1.5 \mathrm{M}$ iodacetamide. Electrophoresis at 3 milliamps/gel was stopped when the marker dye approached the bottom of the gels; the gels were stained in Coomassie brilliant blue and de-stained electrophoretically. Electrophoretic mobility was calculated distance marker dye/pre-stained gel length $\times$ distance band/post stained gel length. To verify that the abnormal bands were $\operatorname{IgA}$, the gels were longitudinally sliced, one section being stained and the other placed in agar containing anti-IgA and cross electrophoresis at 0.25 milliamps $/ \mathrm{cm}$ was performed.

Serum cholesterol and triglyceride estimations and lipid electrophoresis were performed by the methods discussed by Lewis and Niteckis (1970). Post-heparin lipolytic activity was assayed according to Boberg (1970). Ultracentrifugation was performed using the method of Hatch and Lees (1968).

\section{Results}

Electrophoresis and immunoelectrophoresis confirmed the presence of a migrating kappa $\operatorname{IgA}$ ' $M$ ' band with suppression of immunoglobulins $G$ and $M$ (Fig. 2). No other abnormal precipitates in the immunoelectrophoresis plate were noted apart from non-specific staining at the origin. The results of gel filtration are seen in Fig. 4, the polymeric nature of the IgA being observed, with no IgA in the void volume, this being occupied by very low density lipoprotein (VLDL). The polymers of IgA were verified in SDS PA gels and the abnormal bands were confirmed by cross electrophoresis in agar containing anti-IgA. The 7S-19S fractions from gel filtration were also electrophoresed in SDS PA gels and the mobility for the abnormal bands plotted against molecular weight as depicted in Fig. 5. An unexpected finding was the double bands for each member of the polymer series, the difference between the

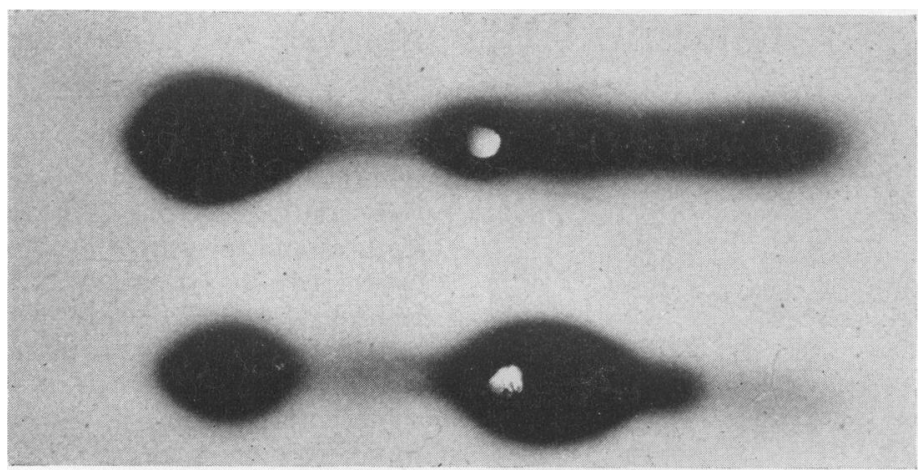

FIG. 2. Electrophoretic pattern in $1 \%$ agarose stained for protein. Upper, normal serum; lower, patient's serum. Anode on left. 
FIG. 3. Lipogram, stained with Oil Red $\mathrm{O}$ in $1 \%$ agarose. Upper, normal serum; lower, patient's serum. Anode on left.
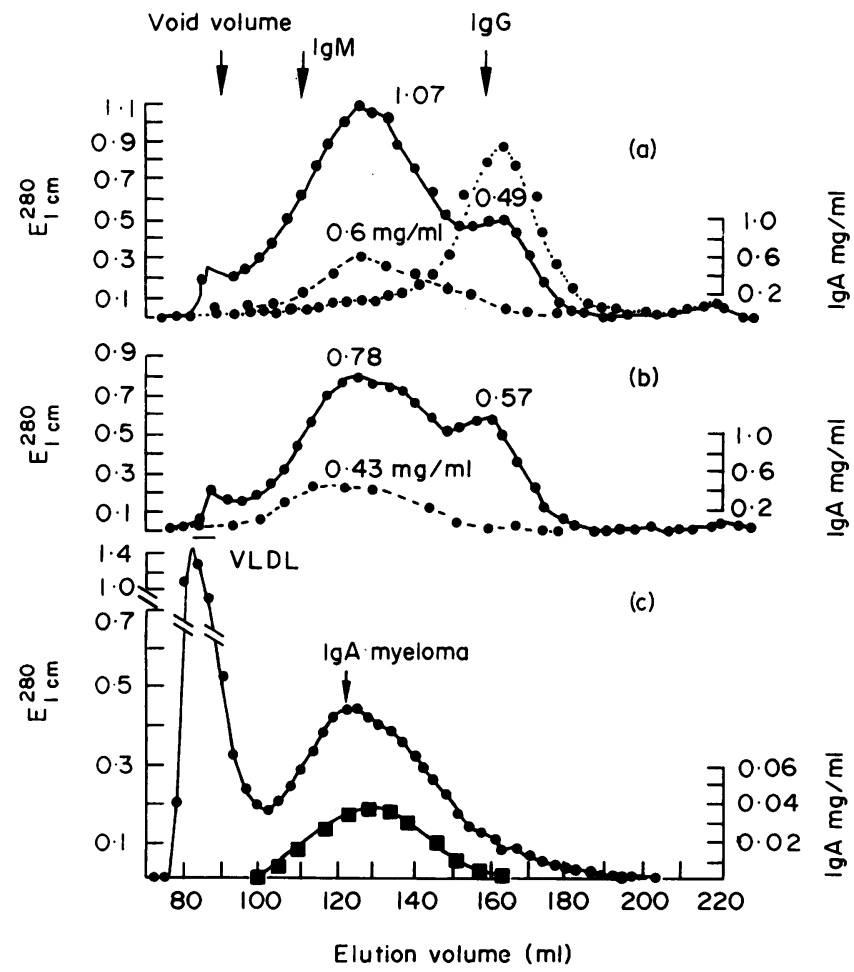

Fig. 4. Gel chromatography studies. (a) Profile of patient's serum at diagnosis: - patient's serum; ... ......, normal serum; .. -. -., IgA in eluant of patient's serum. (b) Patient's serum following therapy (2 months later). (c) Gel filtration of isolated VLDL + IgA myeloma protein showing lack of association. 


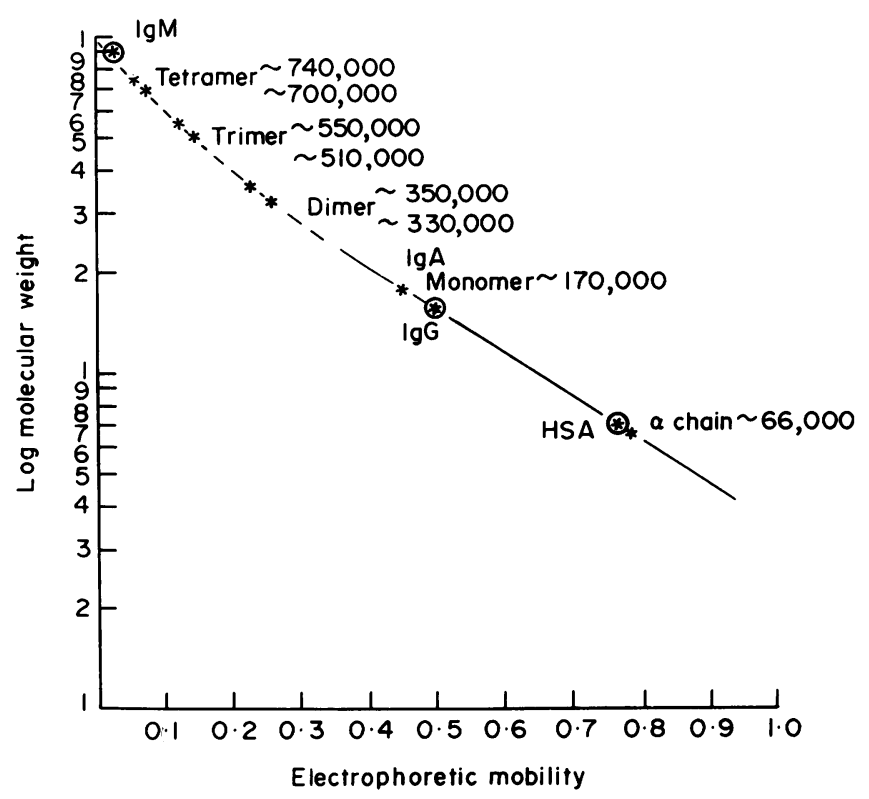

FIG. 5. Molecular weights of abnormal bands seen in SDS polyacrylamide electrophoresis and of $\alpha$ chain on reduction and alkylation.

two members of each individual polymeric species being $20-40,000$ daltons. On complete reduction and alkylation, $\alpha$ chain with mol. wt 66,000 and light chain (and presumably $\mathbf{J}$ chain) were obtained (Fig. 5).

Fasting serum cholesterol and triglycerides were $242 \mathrm{mg} / 100 \mathrm{ml}$ and $5.7 \mathrm{~mm} / 1$ respectively (normal upper limit $2 \mathrm{~mm} / \mathrm{l}$ ). The abnormal lipoprotein pattern consisted of a heavy band occupying the preposition on agarose gel and cellulose acetate electrophoresis. The ultracentrifugation results are as depicted in Table 1; similar results were obtained on a further serum sample.

It has been suggested (Glueck et al., 1969) that one mechanism for hyperlipidaemia in myelomatosis is an inactivation of the lipoprotein lipase system by a heparin-binding antibody associated with the paraprotein; this would have the effect of decreasing uptake of triglyceride from plasma, especially by adipose tissue and muscle. To assess this process we twice measured lipolytic activity in plasma after injection of heparin. The post-heparin lipolytic activity $10 \mathrm{~min}$ after 500 units heparin was 0.25 and $0.35 \mu \mathrm{Eq} / \mathrm{min} / \mathrm{ml}$ (laboratory normal range $0 \cdot 25-0 \cdot 45)$.

Thirty minutes after the heparin injection there was a $14 \%$ fall in serum triglyceride concentration (mean of two measurements before and two after heparin).

In addition, we sought evidence for a lipoproteinbinding antibody associated with the IgA protein, such as has been described by Beaumont (1967).

Using double immunodiffusion in $1 \%$ agarose, chromatographically-isolated IgA from the patient was set up against the three ultracentrifuged lipoprotein classes from the patient's serum and from a normal serum sample: no interaction was detectable. We also carried out rocket electrophoresis of the patient's serum and of his three lipoprotein classes

TABLE 1. Ultracentrifugation studies

\begin{tabular}{|c|c|c|c|c|}
\hline & \multirow[b]{2}{*}{ Patient } & & \multicolumn{2}{|c|}{$\begin{array}{c}\text { Normal } \\
\text { (men 40-69 years) }\end{array}$} \\
\hline & & & Mean & 95th percentile \\
\hline VLDL & $\begin{array}{l}\text { Cholesterol } \\
\text { Triglycerides }\end{array}$ & $\begin{array}{c}102 \mathrm{mg} / 100 \mathrm{ml} \\
4.6 \mathrm{mM} / 1\end{array}$ & $\begin{array}{c}22 \mathrm{mg} / 100 \mathrm{ml} \\
0.69 \mathrm{mM} / 1\end{array}$ & $\begin{array}{l}55 \mathrm{mg} / 100 \mathrm{ml} \\
2.08 \mathrm{mM} / 1\end{array}$ \\
\hline LDL & $\begin{array}{l}\text { Cholesterol } \\
\text { Triglycerides }\end{array}$ & $\begin{array}{l}83 \mathrm{mg} / 100 \mathrm{ml} \\
0.41 \mathrm{mM} / 1\end{array}$ & $160 \mathrm{mg} / 100 \mathrm{ml}$ & $215 \mathrm{mg} / 100 \mathrm{ml}$ \\
\hline HDL & $\begin{array}{l}\text { Cholesterol } \\
\text { Triglycerides }\end{array}$ & $\begin{array}{l}45 \mathrm{mg} / 100 \mathrm{ml} \\
0.25 \mathrm{mM} / 1\end{array}$ & - & - \\
\hline
\end{tabular}


into agarose gel containing anti-human $\operatorname{IgA}$; on staining with fat red $7 \mathrm{~B}$, no lipid-containing rockets were detected.

The selective immuno-electrophoresis Radl procedure was carried out by Dr Brenda Slavin: the patient's serum was electrophoresed into agarose gels containing antisera prepared in this laboratory to the three main apolipoprotein groups, apo-A, apo-B and apo-C, and into control gels not containing antiserum. Subsequently, anti-IgA was added to the troughs; the pattern of the arcs was not affected by the presence of antisera to lipoprotein peptides.

VLDL from two patients with Type IV hyperlipidaemia, and $\operatorname{IgA}$ myeloma protein, were partially purified by repeated gel filtration and verified by immunoelectrophoresis and electrophoretic mobility and staining.

No association could be detected in gel filtration between purified IgA myeloma protein from the patient and VLDL from the two other patients (Fig. 4). It is realized that the dilution during gel filtration could cause dissociation of a weak IgA/ lipoprotein union. No precipitation was seen when both the patients' serum and purified patients' IgA were diffused in agar using standard double diffusion techniques, against sera from a number of normal and pathological sera (including the patients' own serum).

\section{Discussion}

A review of the literature has revealed some twenty-seven reports of similar cases. The first observation was probably reported by Cremer in 1937 (cited by Neufeld, 1964). Males predominate in the ratio $4: 1$ and generally present in their sixth decade with cutaneous xanthomatosis. A minority has a positive family history of xanthomatosis and/or hyperlipidaemia (Kayden, Franklin and Rosenberg, 1962; Osserman and Takutsuki, 1963; Cohen et al., 1966). After a short but variable period, symptoms and signs of myelomatosis follow. Associated atheromatous occlusive vascular disease is a common feature (Lewis and Page, 1965).

Cutaneous xanthomata tend to be generalized and persistent and of an 'eruptive' maculopapular nodular nature and are especially prominent in the palmar creases and extensor surfaces of the elbows and knees (Cohen et al., 1966). Visceral (Brehmer and Lubbers, 1950; Levin et al., 1964) and marrow (Short, 1964) xanthomatosis has also been described. Xanthomata are sometimes absent (Waldenström, 1952; Ozer et al., 1970) and cutaneous xanthomatosis without palmar lesions can occur (Frame, Pachter and Nixon, 1961 ; Marten, 1963; McKenzie, 1964).

The xanthomata in this patient were of an eruptive type on elbows, knees and trunk and there were palmar xanthomata in the palmar streaks (Fig. 1). The palmar streaks are usually a feature of the 'broad $\beta$ ' (Type III) hyperlipoproteinaemia but have also been seen in pre- $\beta$-hyperlipoproteinaemia (Chait, A. and Lewis B., unpublished).

Usually in this condition, xanthomatosis is associated with hyperlipidaemia but cases have been recorded with xanthoma despite normal levels of blood lipids (Marten, 1963; Thannhauser, 1958; Kint, 1961). A turbid serum with elevated cholesterol and triglyceride is, however, the most common abnormality. Ultracentrifugation has demonstrated quantitative (Lennard-Jones, 1961 ; Mullinax, Himrod and Berry, 1971) and qualitative defects (Beaumont et al., 1967; Cohen et al., 1966; Lewis and Page, 1965) in both very low density and low density lipoproteins. The myeloma protein is usually an IgA (Beaumont et al., 1967; Ozer et al., 1970;) occurring twice as commonly as IgG (Kayden et al., 1962; Cohen et al., 1966; Levin et al., 1964).

If IgA paraprotein is present it can be either predominantly monomeric (Ozer et al., 1970) or polymeric (Lewis and Page, 1965). The hyperviscosity syndrome has previously been reported in this disorder (Beaumont et al., 1967) and is probably due to the large number of circulating high molecular weight protein molecules.

Cytotoxic therapy and dietary manipulation do not usually affect the serum lipids (Beaumont et al., 1967; Lewis and Page, 1965; Lennard-Jones, 1961; but some workers have observed depression of blood lipids with therapy using D penicillamine which may be immunosuppressive (Beaumont et al., 1967; Mullinax et al., 1971). The course and duration of this clinical entity appears to be similar to that of the myeloma component. As seen in Table 2, myocardial infarction is frequently the cause of death, and coronary and peripheral vascular disease is frequently evident during life.

In some cases, evidence has been presented for immune complex formation between the myeloma protein and the lipoprotein, the affinity between the components of the complex varying from strong (Beaumont et al., 1967; Lewis and Page, 1965) to weak (Beaumont, 1969; Kayden et al., 1962). Other authors (Osserman and Takutsuki, 1963; Cohen et al., 1966), even after extensive investigation, could not demonstrate any complex formation.

The present case of myeloma with hyperlipidaemia has many features similar to those described in the literature for this entity. The myeloma was of a kappa IgA polymeric variety, but the nature and significance of the doublets in the polymer series is not known although it is also seen in other $\operatorname{IgA}$ polymeric myelomas without lipaemia (unpublished observation). On complete reduction and alkylation 
TABLE 2. Clinical features of twenty-seven cases of myeloma and hyperlipidaemia with xanthomatosis $\dagger$

Myeloma (27)*

Hyperlipidaemia (24)

Xanthomatosis (20)

Family history of xanthomatosis

Family history of serum lipid disorders

Sex ratio (20)

Age at diagnosis (19)

Presentation (13)

Mean duration (10)

Clinical evidence for occulusive atheromatous disease (10)

Cause of death (10)

Myeloma type (14)

Bence Jones proteinuria (9)

Osteolytic lesions (12)

Hyperviscosity Syndrome

* Number refers to number of cases where information is available.

+ Data from references cited.

of this paraprotein only $\alpha$ chain and light chain (and $J$ chain) were noted. On ultracentrifugation, the abnormal lipoprotein floated at a background density of 1.006 retaining pre- $\beta$ mobility. The D 1.006 fraction contained $46 \%$ of the total serum cholesterol and $88 \%$ of the total serum triglyceride. The features were those of elevated VLDL or pre- $\beta$-lipoprotein levels (Type IV in WHO classification). As sometimes occurs in this abnormality, low-density lipoprotein (LDL) cholesterol was low (below fifth percentile).

There was no evidence in this patient of impairment of the response to injected heparin as assessed by measurments of lipolytic activity and by the fall in serum triglyceride concentration. There was no evidence for an unrelated aetiology for his hyperlipidaemia: no relative had xanthomata or premature ischaemic heart disease; his alcohol intake was negligible, there was normal glucose tolerance and the blood urea was normal.

In this patient no definite evidence could be obtained to suggest the aetiology of the lipid abnormality. Immune complex formation as the mechanism for the hyperlipidaemia in this patient appears unlikely in view of the following findings: (1) the lack of abnormal precipitate arcs in immunoelectrophoresis of the patient's serum; (2) the negative findings using the method of Radl as described above; (3) the absence of any detectable activity of the patient's serum and isolated IgA myeloma protein against the patient's and other sera in agar double diffusion experiments; (4) the absence of any detectable activity of the patient's isolated protein against the patient's and normal lipoprotein classes; (5) the lack of $\operatorname{IgA}$ in the biopsied xanthoma; (6) the lack of lipid depression with effective cytotoxic therapy.

We have, therefore, failed to show the presence of lipoprotein antibody in this patient's $\operatorname{IgA}$ and could not demonstrate the presence of circulating immune complexes containing lipoprotein. Although the clinical association of myeloma and a lipoprotein abnormality appears to be a definite clinical entity we were unable to identify the mechanism for this patient's hyperlipidaemia. Beaumont has suggested that one mechanism for the hyperlipidaemia in this entity is due to the anti-lipoprotein antibody activity of the myeloma protein. Glueck has demonstrated that a second mechanism may occur with the presence of heparin-binding antibodies and subsequent interference in the lipoprotein lipase system. A further mechanism, as yet unidentified, may exist, as seen in the present patient.

\section{Acknowledgments}

We wish to thank Dr J. Holt, consultant physician and Medical Tutor at the Radcliffe Infirmary, for his permission to report this case and to Dr J. Mann, Dr R. W. Turner and Dr I. C. M. MacLennan for their advice and encouragement.

\section{References}

Beaumont, J.L., Jacotot, B. \& Beaumont, V. (1967) L'hyperlipidémie par auto-anticorps. La Presse Médicale, 46, 2315.

BEAUMONT, J.L. (1969) Un deuxième type d'auto-anticorps anti-lipoprotéine de myélome: l'IgG anti-Lp Al. Sa. Comptes Rendus Hébdomadaires des Séances de l'Académie des Sciences; D: Sciences Naturelles (Paris), 269, 107.

BOBERG, J. (1970) Quantitative determination of heparin released lipoprotein lipase activity in human plasma. Lipids, 5, 452.

BreHMER, W. \& LubBers, P. (1950) Über eine generalisieste Xanthomatose mit Knochenbefall und diffuser Plasmafell Wecherung im Knockenmark bei essentieller Hyperlipamie. Virchows Archiv für pathologische Anatomie und Physiologie und für klinische Medizin, Berlin, 318, 394.

Cohen, L., Blaisdell, R.K., DJordejich, J., ARmiste, V. \& DoBbrilovic, L. (1966) Familial xanthomatosis and hyperlipidemia and myelomatosis. American Journal of Medicine, 40, 299.

Cremer, J. (1937) Retikulose mit leberxanthomatose. Zentralblatt für allgemeine Pathologie und pathologische Anatomie, 68, 289.

Feiereis, H. \& SeHNert, H.E. (1954) Seltene Form einer Paraproteinose. Klinische Wochenschrift, 32, 998.

Frame, B., PaChter, M.R. \& Nixon, R.K. (1961) Myelomatosis with xanthomatosis. Annals of Internal Medicine, $54,134$.

Fredrickson, D.S., LeVy, A.I. \& LeES, R.S. (1967) Fat transport in lipoprotein-an integrated approach to mechanisms and disorders. New England Journal of Medicine, 276, 21. 
Glueck, C. J., Levy, R.I., Glueck, H.I., Gralnick, H.R. Greten, H. \& Fredrickson, D.S. (1969) Acquired Type I hyperlipoproteinaemia with systemic lupus erythematosus, dysglobulinaemia and heparin resistance. American Journal of Medicine, 47, 318.

Gross, P. \& Weicker, H. (1954) Die Bedeutung des Lipodelek-trophoesediagrammes. Klinische Wochenschrift, 32 , 509.

HATCH, F.T. \& LeES, R.S. (1968) Practical methods for plasma lipoprotein analysis. Advances in Lipid Research, 6, 1 .

Kanzow, U. (1957) Untersuchungen über Serumlipode bei Paraproteinamien. In: European Society of Haematology, Transactions of the 6th Congress, Copenhagen, 1958 (Ed. by A. Videback et al.), pt. 2, p. 103. S. Karger: Basel.

Kayden, H.J., Franklin, E.C. \& RosenberG, B. (1962) Interaction of myeloma globulin with human beta lipoprotein. Circulation, 26, 659.

KINT, A. (1961) Les manifestations cutanées de la maladie de Kahler. Archives Belges de Dermatologie et de Syphiligraphie (Bruxelles), 17, 148.

KNIKER, W.T. \& Cochrane, C.G. (1968) The localization of circulating immune complexes in experimental serum sickness. Journal of Experimental Medicine, 127, 119.

LENNARD-JONES, J.E. (1960) Myelomatosis with lipaemia and xanthomatosis. British Medical Journal, i, 781.

Levin, W.C., Aboumrad, M.H., Ritzmann, S.E. \& Brantly, C. (1964) Gamma-type I myeloma and xanthomatosis. Archives of Internal Medicine, 114, 688.

Lewis, B. \& Niteckis, N. (1970) Plasma lipids and lipoproteins. Annals of Clinical Biochemistry, 7, 118.

LeWIS, L.A. \& PAge, I.H. (1954) Serum proteins and lipoproteins in multiple myeloma. American Journal of Medicine, 17, 670 .

LewIS, L.A. \& PAGE, I.H. (1965) An unusual serum lipoprotein-globulin complex in a patient with hyperlipemia. American Journal of Medicine, 38, 286.

Liebetseder, F., Hugentobler, F., Wunderly. C. \& WuhrMANN, F. (1951) Untersuchungen über die serumlipode und proteine. Wiener Zeitschrift fur innere Medizin und ih, $\cdot$ e Grenzgebiete, 32, 1.

Magalini, S.I., Stefanini, M. \& Martin, H.M. (1956) Diagnostic significance of changes in free, esterified, protein-bound cholesterol, lipo- and glycero-proteins in lymphoma and multiple myeloma. American Journal of the Medical Sciences, 231, 155.
MARTEN, R.H. (1963) Xanthomatosis and myelomatosis. Proceedings of the Royal Society of Medicine, 55, 318.

McKenzie, A.W. (1964) Plane xanthoma, hypercholesterolaemia and myelomatosis. Proceedings of the Royal Society of Medicine, 57, 889.

Mullinax, F., Himrod, B. \& Berry, E.R. (1971) Abstract. Journal of Immunology, 107, 926.

Neufeld, A.H., Morton, H.S. \& Halpenny, G.W. (1964) Myelomatosis with xanthomatosis multiforme. Canadian Medical Association Journal, 91, 374.

Osserman, E.F. \& Takatsuki, K. (1963) Plasma cell myeloma: Gamma-globulin synthesis and structure. Medicine, Baltimore, 42, 357.

Ozer, F.L., Telatar, H., Telatar, F. \& Muftuoglu, E. (1970) Monoclonal gammopathy with hyperlipidemia. American Journal of Medicine, 49, 841.

RADL, J. (1970) Light chain typing of immunoglobulins in small samples of biological material. Immunology, 19, 137.

Riesen, W., Noseda, G. \& Butler, R. (1971) Human myeloma proteins which bind lipoprotein. Protides of the Biological Fluids (Ed. by H. Peeters), 19, 273.

Sachs, B.A., Candy, P. \& Ross, G. (1954) Abnormal lipidlike material and carbohydrate in sera of patients with multiple myeloma. American Journal of Medicine, 17, 662.

SchlESS, G.L. (1958) Serum cholesterol-globulin complex in multiple myeloma. American Journal of the Medical Sciences, 235, 562.

Seitanidis, B.A., Shalman, G. \& Hobbs, J.R. (1970) Low serum cholesterol with IgA myelomatosis. Clinica chimica acta, 29, 93.

SHorT, M.H. (1964) Multiple myeloma with xanthoma formation. Archives of Pathology, 77, 400.

Spain, D.M., Greenblatt, I.J., Snapper, I. \& Cohn, T. (1956) Degree of coronary and aortic atherosclerosis in necropsied cases of multiple myeloma. American Journal of the Medical Sciences, 231, 165.

Thannhauser, S.J. (1958) Lipidoses, third edition, p. 360. Grune and Stratton: New York.

WALDENSTRÖM, J. (1952) Abnormal proteins in myeloma. Advances in Internal Medicine, 5, 398.

WEBER, K. \& OsBorN, M. (1969) The reliability of molecular weight determinations by dodecyl sulphate polyacrylamide gel electrophoresis. Journal of Biological Chemistry, 244, 4406. 